\title{
An Exploration of EFL Learners' Anxiety and E-learning Environments
}

\author{
Peiwen Huang \\ National Formosa University, Taiwan \\ Yanling Hwang (corresponding author) \\ Chung Shan Medical University, Taiwan
}

\begin{abstract}
The world is becoming more and more convenient, with high-tech equipment and computers being invented and applied in various ways. Multimedia materials in the English classroom play a novel role in language learning. At the same time, L2 learners who lack confidence and have low learning motivation suffer poor language performance. The motivation of this study is to assess multimedia instruction in the English classroom. In particular, it will examine the relationship between multimedia environments and English learning anxiety in EFL college students in Taiwan. A questionnaire was given to 124 students on an English course at Chung Shan Medical University. Statistical correlations and a T-test are used to analyze data in this study. The study conducted claims to identify and understand the relationship between multimedia techniques in language teaching and learners' language anxiety. Its results suggest that a multimedia environment can reduce student anxiety and provide a less stressful classroom environment. Put otherwise, multimedia tools enable English teachers to help students to both improve their English performance and lower their language anxiety. Hopefully, the findings of this study could help to reduce EFL college students' language anxiety and contribute to the awareness of language learners' anxiety.
\end{abstract}

Index Terms — language learning, language anxiety, college students, multimedia environments

\section{INTRODUCTION}

The communicative approach to language teaching emphasizes the use of language as a communication tool and hypothesizes that learners become proficient by using the language and not just by learning about the language. Learning English seems to be very difficult for native speakers of Chinese. L2 learners who lack confidence and have low learning motivation tend to perform poorly in the language learning process. Traditional Asian classrooms are a teacher-centered learning setting in which students are passive learners, rather than active learners. Interactions among students and teacher in which individuals share thoughts, ideas and support each others' viewpoints are rare situation in the traditional Taiwanese classroom. This traditional environment negatively influences learning ability by creating anxiety, frustration, depression or suspicion. In such an environment, students' 'affective filters' will screen out many meaningful language messages, thus reducing learners' learning performance. Aggressive emotion and participation, on the other hand, will make L2 learners function effectively.

Anxiety has been regarded as one of the most important negative factors influencing second language acquisition. Spielberger (1983) defines anxiety as "the subjective feeling of tension, apprehension, nervousness, and worry associated with an arousal of the autonomic nervous system." More simply, anxiety is associated with feelings of uneasiness, frustration, self-doubt, apprehension, and worry (Scovel, 1978). Much research (e.g. Bailey, 1983; Horwitz, Horwitz, \& Copes, 1986; MacIntyre \& Charos, 1996; Young, 1991) has paid great attention to investigate the relationship between anxiety and achievement in different foreign languages learning. There are many potential sources of learners' anxiety in the foreign language classroom. As Young (1991) argues, two factors, personal and interpersonal anxieties, have been the most commonly addressed in related anxiety research.

In order to enhance students' learning motivation, scholars have been investigating the best teaching instruction methods for learning English. The efficacy of multimedia has drawn great attention to this issue and is presumed, under the assumption of adding an additional channel of media to transmit a message, to dramatically enhance communication and comprehension (Dwyer, 1978). Multimedia technology (such as TV, computers, networks, Youtube, E-mail, and interactive multimedia) aids the teaching technique of integrating real-life target language situations into the language classroom. In this particular environment, learners gradually develop their language skills by being exposed to genuine target language environments. Hartman (1961) indicated that the multiple-channel theory, involving at least two of the channels under consideration here, increases learners' language comprehension. In accordance with one of the most prominent theories of second language acquisition, Krashen (1985) proposed that learners can learn a large amount of language unconsciously where there is ample comprehensible input. In other words, language acquisition only takes place when comprehensible input is delivered sufficiently. In this respect, language teachers strive to employ a wide variety of teaching techniques to create authentic situations and to promote learners' language acquisition.

Nowadays the use of the multimedia materials is extensive and prevailing in education, as well as in recreation and communication. This new dimension involves the knowledge of foreign languages as a basic requirement (Tamburini, 1999). The implementation of multimedia teaching is also an innovative method in Taiwan, where teachers apply 
multimedia such as audio, video, animation and interactivity in their class. These materials can give the impetus to previously passive students who might now be more attracted to learning and therefore pay more attention to classroom learning. The multimedia teaching approach emphasizes interaction between a teacher and students, unlike the traditional one-way teaching method. In order to increase students' motivation to learn English, computer software is used to enhance student stimulation. With these kinds of needs, there are more and more schools trying to integrate computers into their English language courses. With this in mind, the present study focuses on how the computer-assisted learning makes students enjoy the learning process and reduces their English anxiety.

In Taiwan, there was several research conducted in the filed of language anxiety among different groups. Language anxiety has been addressed from the differ perceptives from primary, junior/senior high and college students. However, this research suggested that few research studies have focused on language anxiety in EFL College students in multimedia environments.

Purpose of study

This study aims to investigate the correlation between EFL students' language anxiety and the use of multimedia instruction in English classrooms. This subject is investigated in order to find out how to best utilize the multimedia teaching method as a means to reducing language learning anxiety.

In order to carry out this analysis, this study aims to answer the following questions:

1. What is the level of EFL college students' language anxiety?

2. To what extent do students perceive that a multimedia environment can alleviate language anxiety?

3. Is there any significant difference between male and female language anxiety?

4. What forms of multimedia instruction are preferred by EFL students?

\section{LITERATURE REVIEWS}

\section{A. Definition of Multimedia}

Multimedia is the combination of various forms of media in an interactive manner. This is in contrast to a single media employed on its own. An educational example of multimedia is the use of computer-based training to integrate the course content with the implementation of multimedia. Computers with video, audio function have become a common equipment in students' learning activities, as well as in their leisure time. These have become major tools to help students to learn English in more interesting ways. Computer-assisted learning in particular is being adopted by more and more colleges in their English courses and students are even using it in independent English learning.

Regarding the use of CALL (Computer-assisted language learning), multimedia plays an important role, providing students with a bidirectional and individualized learning method. The multimedia teaching approach can integrate with various teaching elements, for example, Power Point files or Word Process files. In general, the functions of multimedia are that it can record, preserve and display information.

\section{B. The Studies of CALL}

Computer-assisted language learning (CALL) can help students practice their linguistic skills. For example, some students are not very good at pronunciation or reading due to the lack of appropriate environments in which to practice. With CALL, such students can enhance their phonological ability and get more chance to immerse themselves in a foreign language environment. Torgesen (1995) found that the phonological awareness skills of those struggling with reading can be improved with computer-assisted training. Computers provide more chance for students to watch items as many times as they want (Torgesen,1995). Computer based learning practice can also enhance students' performance on reading and memory. Tsou et al. (2006) suggest that students using CALL can recall more content of a foreign language story, generate much more complex sentences, and demonstrate better language proficiency. Furthermore, it has been suggested that computer-assisted vocabulary learning using images can have positive dynamic effects on students' reactions and classroom participation (Chang et al., 2005).

CALL plays an important role in teaching that focuses on interaction, and individualized teaching. CALL can make up for the shortcomings of traditional one-way teaching methods, replacing it with two-way language teaching. The benefits of CALL are that it can combine text, sound effects and images in order to increase the diversity of teaching and to promote learning efficiency by inspiring students' learning desire. A previous study by Hwang (2010) highlights the advantages of CALL as follows:

1. CALL can increase the learning effect by facilitating the repetition of learning exercises.

2. CALL can make study more interesting, enhancing students' learning desire.

3. CALL can achieve the goal of applied English learning through simulated teaching content.

4. CALL provides assistance and lesson content that learners can help themselves to.

In other words, the CALL can increase the opportunities for interaction, individualize learning, generate immediate feedback, encourage students to learn actively and monitor students learning conditions easily.

Blake (1998) claims several beneficial effects of a well-designed CALL lesson. The lesson provide appropriate feedback, foster a communicative environment, offer branching, treat the subject matter in context, follow problem-solving or discovery producers, and allow the student autonomy or control. Underwood (1984) lists twelve premises for CALL. He also mentions the use of e-mail as a means of using networked computer to send messages between learners and instructors. 


\section{Multiple-channel Learning Theories}

Hartman (1961) indicated that the multiple-channel theory, involving at least two of the channels under consideration here, increases learners' comprehension by providing interaction between any combination of the different available sensory channels. Dwyer (1978) refers to the multiple-channel theory as simultaneous presentation of stimuli through different sensory channels. Moore, Burton, and Mayers (1995) carried out a study and examined learners' ability to access aural and visual stimuli simultaneously and what amount of information could be processed. Their findings led them to the conclusion that the multiple-channel learning theory promotes learning. In a sense, developers and educators have captured the value of multiple-channel learning and have selected appropriate media for its application.

There is an abundance of research that supports the effectiveness of multi-channel learning. Hartman's (1961) research indicates that learning is enhanced when both audio and print means are employed simultaneously. However, he suggests that print alone should be employed by literate students studying complicated materials, whereas audio is beneficial when the material is simple or the subjects are illiterate. Moreover, Levie and Lentz (1982) contend that these two channels reinforce each other and enhance both recall and comprehension.

\section{Language Learning Anxiety}

Second language learning coming along with a particularly anxiety-provoking experience has several reasons. First, Young (1999) argued that when students are asked to deliver their thoughts or idea with a foreign language in which they have limited competence, their performance can be very threatening to their self-image. According to Horwitz et al (1986) "performance in the L2 is likely to challenge an individual's self-concept as a competent communicator" and this might lead to "reticence, self-consciousness, fear or even panic." In accordence with this position, communication apprehension has been reveal to affect one's willingness to communicate in the L2(MacIntyre \& Charos, 1996; Yashima, 2002, Yashima, et al., 2004).

Secondly, Scovel (1978) states the affective factors deal with the emotional reactions and motivations of the learner as conducting the study on the effect of affective factors on language learning. He claims that one of the most affective variables in learning tasks is anxiety. Moreover, Scovel (1978) and Young (1991) agree that too much anxiety can have a debilitating effect on language learning. The facilitating or debilitating aspect of anxiety is difficult to measure in the language learner.

Horwitz et al. (1986) listed three elements of foreign language anxiety: (1) communication apprehension, (2) fear of negative evaluation, and (3) test anxiety. Communication apprehension results from the fear of the real or expected interactions with others. Fear of negative evaluation arises when a learners' need to make a positive social impression on others leads to a despondent mood. Test anxiety results from the experience of failure. Here the level of anxiety is proportionate to the excessive memory that accompanies the experience of failure (Aida, 1994).

According to Horwitz and Young (1991), there are two classification to explain language anxiety: (1) language anxiety may be the result of more general types of anxiety, such as test anxiety or the communication apprehension found in shy people; or (2) language anxiety may be a specific response to language learning. Thus factors unique to langue learning cause some people to be nervous. To sum up, anxiety contributes to the affective filter of Kranhen's Monitor Model.

\section{E. Krashen's Affective Filters Hypothesis}

Stephen Krashen $(1985,1999,2005)$ proposed one of the most controversial theoretical perspectives in SLA. Krashen has addressed five hypotheses in learning process: the Acquisition/Learning Hypothesis, the Natural Order Hypothesis, the Monitor Hypothesis, the Input Hypothesis, and the Affective Filter Hypothesis. According to Krashen (1985), learning a second language (L2) is very much like learning a first language (L1). No conscious effort needs to be made to focus on the language. If people are exposed to the target language by hearing or reading, the ability to speak and to write will come more or less at their own pace. In the field of L2 research much attention has been focused on the central role of acquisition of cognitive academic skills. The Comprehensible Input Hypothesis (Krashen, 1985) revealed that students learn new language which includes vocabulary, meaning, pronunciation and sentence structures already acquired and taught, coupled with language that is new. In other words, the Comprehensible Input Hypothesis is Krashen's explanation of how second language acquisition takes place, concerning with acquisition, not learning. According to this hypothesis, the L2 learner improves and progresses through the developmental stage of natural orders when one receives second language input that is one level beyond one's current stage of linguistic competence. For example, if a learner is at a stage I, then acquisition takes place when he / she is exposed to comprehensible input that is at level I+1. Consequently, their speech and grammar knowledge is automatically provided by input that is both comprehensible and of sufficient quantity. The ability to produce language is said to emerge naturally and need not be taught directly. In this regard, instructors can provide students with authentic, meaningful, comprehensible language that is not easily available to them so that their acquisitions take place automatically. The teaching implications are to supply the class time with abundant comprehensive input in order to activate learners' acquisition unconsciously.

In the Affective Filter Hypothesis, Krashen argues that there exists a "filter" or "mental block" that impedes L2 from "getting in". A low filter is associated with relaxation, confidence to take risks and a pleasant learning environment. When the anxiety level is high, the affective filter is high. It makes the learners unreceptive to language input and decreases language acquisition. Krashen further claims that the best acquisition will take place in an environment where anxiety-provking is low and defensiveness absent, or, in Krashen's terms, in contexts where the "affective filter" is low. When learners sitting in a class are very nervous and anxious about the possibility of being called on, they may not pay 
attention to what the teacher is saying and will benefit very little from being in class.

\section{Methodology}

\section{A. Participants}

The subjects of this study were 124 freshman students at Chung Shan Medical University whose majors were not English. The study was carried out in the fall semester of 2010. Participants' ages ranged from 18 to 20. Most of them had been studying English for about seven years.

\section{B. Instrument}

The questionnaire (see appendix), as the instrument of this study, was designed specifically for the present study and is composed of three parts. The first part of the questionnaire elicits basic demographic information, including gender and year in school. The second part of the questionnaire reproduces the Foreign Language Classroom Anxiety Scale (FLCAS) that was designed by Horwitz, Horwitz, \& Copes (1986). This part consists of 33 statements. The last part of this survey investigates students' perception of learning English in a multimedia environment. This part consists of 20 questions. For all but one of the questions in the third section, respondents are asked to rank their agreement with a statement on a 5-point Likert scale. Question 20 of part three is an open-ended question.

In order to ensure appropriateness of the questionnaire's content, it was first distributed to three experienced English teachers at a cooperating college to prevent the question items from containing ambiguity, irrelevance. In addition to this, a group of five students were distributed the questionnaire prior to the actual study. The results of the question items were investigated and validated in terms of internal reliability, test-retest reliability and construct validity. Cronbach's alpha reliability coefficient for this instrument is 0.87 .

\section{Procedure}

To begin with, the English classroom used by the subjects of this research is equipped with multimedia and computer equipment. During the 17-week semester, multimedia instruction, such as video watching, online English exercises, Youtube presentations, and powerpoint file presentations, were delivered and presented in English class. At the end of the 2010 fall semester, the non-English major freshmen were asked to fill out my questionnaire. This took about 40 minutes to complete and was administered during the students' regular English class. After the questionnaire scores were received, an SPSS statistical package was used to analyze them. A T-test was carried out in order to examine any difference between male and female levels of learning anxiety.

\section{ReSUlTS AND DisCUSSION}

Table 1 and 2 show the results for EFL learners' English anxiety in the classroom. These results are derived from part II of the questionnaire, which was adopted from Horwitz's Foreign Language Classroom Anxiety Scale (FLCAS) (1986). Table 1 presents the mean value for overall learner anxiety as 3.06. This is close to the average $(\mathrm{M}=3.00)$. This is inconsistent with previous research by Huang (2011), which reports a higher mean of overall language anxiety at 3.14. This indicated that the level of language anxiety in subjects was slightly lower than in Huang's research. The highest scores for anxiety related to item 10, "I worry about the consequences of failing my foreign language class" (M=3.52), whereas the lowest scores were for item 17, "I often feel like not going to my English class" (M=2.58).

TABLE 1.

MEAN AND STANDARD DEVIATION OF FOREIGN LANGUAGE CLASSROOM ANXIETY

\begin{tabular}{|l|l|l|l|}
\hline & $\mathrm{N}$ & Mean & SD \\
\hline FLCAS (partII) & 124 & 3.06 & .513 \\
\hline
\end{tabular}


TABLE 2

DESCRIPTIVE STATISTICS OF FOREIGN LANGUAGE CLASSROOM ANXIETY SCALE

\begin{tabular}{|c|c|c|c|}
\hline & & Mean & SD \\
\hline 1. & I never feel quite sure of myself when I am speaking in English. & 2.97 & .94 \\
\hline 2. & I don't worry about making mistakes in English classes. & 3.15 & 1.05 \\
\hline 3. & I tremble when I know that I'm going to be called on in English class. & 3.15 & 1.04 \\
\hline 4. & It frightens me when I don't understand what the teacher is saying in English. & 3.18 & 1.02 \\
\hline 5. & It wouldn't bother me at all to take more English classes. & 2.90 & .93 \\
\hline 6. & During English class, I find myself thinking about things that have nothing to do with the course. & 2.60 & .97 \\
\hline 7. & I keep thinking that the other students are better at English than I am. & 3.10 & 1.02 \\
\hline 8. & I am usually at ease during tests in my English class. & 3.02 & 1.03 \\
\hline 9. & I start to panic when I have to speak without preparation in English class. & 3.45 & 1.16 \\
\hline 10. & I worry about the consequences of failing my English class. & 3.52 & .92 \\
\hline 11. & I don’t understand why people get so upset over English class. & 3.00 & .96 \\
\hline 12. & In English class, I can get so nervous I forget things I know. & 3.37 & 1.05 \\
\hline 13. & It embarrasses me to volunteer answers in my English class. & 3.43 & 1.10 \\
\hline 14. & I would not be nervous speaking English with native speakers. & 3.04 & .99 \\
\hline 15. & I get upset when I don't understand what the teacher is correcting. & 3.09 & 1.11 \\
\hline 16. & Even if I am well prepared for English class, I feel anxious about it. & 3.08 & 1.11 \\
\hline 17. & I often feel like not going to my English class. & 2.58 & .94 \\
\hline 18. & I feel confident when I speak in my English class. & 3.31 & .93 \\
\hline 19. & I am afraid that my English teacher is ready to correct every mistake I make. & 2.66 & .96 \\
\hline 20. & I can feel my hear pounding when I am going to be called on in my English class. & 3.09 & .95 \\
\hline 21. & The more I study for an English test, the more confused I get. & 2.78 & 1.03 \\
\hline 22. & I don’t feel pressure to prepare very well for English class. & 3.19 & 1.03 \\
\hline 23. & I always feel that the other students speak English better than I do. & 3.28 & .97 \\
\hline 24. & I feel very self-conscious about speaking English in front of other students. & 3.06 & .93 \\
\hline 25. & English class moves so quickly I worry about getting left behind. & 2.83 & 1.00 \\
\hline 26. & I feel more tense and nervous in my English class than in my other classes. & 2.72 & 1.14 \\
\hline 27. & I get nervous and confused when I am speaking in my English class. & 2.91 & 1.02 \\
\hline 28. & When I'm on my way to English class, I feel very sure and relaxed. & 2.86 & .84 \\
\hline 29. & I get nervous when I don't understand every word the English teacher says. & 3.16 & 1.08 \\
\hline 30. & I feel overwhelmed by the number of rules you have to learn to speak English. & 2.95 & .81 \\
\hline 31. & I am afraid that the other students will laugh at me when I speak English. & 2.84 & 1.10 \\
\hline 32. & I would probably feel comfortable around native speakers of English. & 3.40 & .94 \\
\hline 33. & I get nervous when the English teacher asks questions which I haven't prepared in advance. & 3.42 & .91 \\
\hline
\end{tabular}

The present study is also inconsistent with the findings of the average mean obtained in the previous studies by $\mathrm{Na}$ (2007), Chan and Wu (2004), who obtained 2.9 and 2.96 respectively. The findings showed that the tendency to feel foreign language anxiety on the part of the college students was obvious. Moreover, their level of anxiety is higher than that of elementary $(M=2.9)$ and high school $(M=2.96)$ students. Language teachers should sustain a good relationship with students in order to lower their anxiety and to facilitate their language learning. In other words, language teachers need to be aware of the existence of foreign language anxiety and to acknowledge that language classes can be treating for some students. To conquer the problem, language teachers should help create the learning environment less stressful.

The second question that this paper set out to answer "To what extent do the students perceive that a multimedia environment can alleviate language anxiety?" is addressed in part three of the questionnaire. This focuses on participants' perceptions of studying English in multimedia environments. Table 3 presents the five statements with which students most agreed. Interestingly, three out of five multimedia learning items that students viewed most positively can be easily facilitated by a computer. In other words, the flexibility and practicality of using computer-assisted language learning is feasible in the classroom. Interestingly, more than 50\% of students like to work cooperatively with their group to carry out group presentations. Cooperative learning requires that students participate actively in the group and consult with each other.

TABLE3.

THE PERCENTAGES OF THE STRONGLY AGREE ON TOP FIVE QUESTION ITEMS ON PART III

\begin{tabular}{|c|c|c|c|c|c|c|}
\hline & strongly agree & agree & Either agree or disagree & disagree & Strongly disagree & Mean \\
\hline $\begin{array}{l}\text { 11. I like to learn English through } \\
\text { songs. }\end{array}$ & $34.7 \%$ & $47.1 \%$ & $10.7 \%$ & $7.4 \%$ & $0 \%$ & 4.09 \\
\hline $\begin{array}{l}\text { 16. I think multimedia (i.e.: } \\
\text { computers, DVD, Youtube, } \\
\text { PPT ) is a good teaching } \\
\text { instruction to learn English. }\end{array}$ & $26.7 \%$ & $53.3 \%$ & $14.2 \%$ & $5.0 \%$ & $.8 \%$ & 4.00 \\
\hline $\begin{array}{l}\text { 5. Watching video in English class } \\
\text { also interests me to learn English. }\end{array}$ & $24.8 \%$ & $52.1 \%$ & $16.5 \%$ & $5.0 \%$ & $1.7 \%$ & 3.93 \\
\hline $\begin{array}{l}\text { 1. I learn how to work with others } \\
\text { from the group presentation in } \\
\text { class. }\end{array}$ & $9.0 \%$ & $46.7 \%$ & $37.7 \%$ & $4.9 \%$ & $.8 \%$ & 3.84 \\
\hline $\begin{array}{l}\text { 6. I think English captions help me } \\
\text { understand the conversation better }\end{array}$ & $19.0 \%$ & $52.1 \%$ & $21.5 \%$ & $6.6 \%$ & $.8 \%$ & 3.82 \\
\hline
\end{tabular}

Table 4 shows the correlation between agreement with question 33, "I think multimedia instruction can reduce my English Learning Anxiety", and with question 32, "I think multimedia instruction is a good teaching instruction to learn 
English". The Cronbach's Alpha correlation coefficient showed there was a significant positive correlation between these two responses $(r=0.439$. $\mathrm{p}<.05)$. This positive relationship suggests that participants believe that multimedia environments enhance their language learning.

TABLE4.

CORRELATION BETWEEN LANGUAGE ANXIETY AND MULTIMEDIA ENVIRONMENTS

\begin{tabular}{|l|l|l|l|}
\hline & N. & Mean & SD. \\
\hline FLCAS & 127 & 3.06 & .513 \\
\hline \multicolumn{4}{rl}{$r=.439^{*}$} \\
$\mathrm{p}<.05$
\end{tabular}

The results relevant to the third question considered by this study, which discusses the impact of gender on language anxiety, are presented in table 5. The T-test results suggest that there is not a significant difference between the levels of language anxiety in males and females. However, the level of learning anxiety of female students was a little higher than that of male students. The unequal numbers of females and males could lead to this result.

TABLE 5.

THE RELATIONSHIP BETWEEN STUDENTS' GENDER AND LANGUAGE ANXIETY

\begin{tabular}{|l|l|l|l|l|l|}
\hline \multicolumn{7}{|c|}{ THE RELATIONSHIP BETWEEN STUDENTS' GENDER AND LANGUAGE ANXIETY } \\
\hline \multirow{2}{*}{ FLCAS (PartII) } & Male & $\mathrm{N}$ & Mean & Std. Deviation & Std. Error Mean \\
\cline { 2 - 7 } & Female & 34 & 3.07 & .47 & .080 \\
\hline
\end{tabular}

Further analysis focused on the difference between male and female responses to individual question items. The results of this analysis indicate that there is a significant difference between male and females responses to question 11 in part three. Female students show a greater interest in learning English through songs (see Table 6).

TABLE6.

THE RELATIONSHIP BETWEEN MALE AND FEMALES RESPONSES TO QUESTION 11

\begin{tabular}{|l|l|l|l|l|l|}
\hline Group & & $\mathrm{N}$ & Mean & Std. Deviation & Std. Error Mean \\
\hline I like to learn English & Male & 34 & 3.82 & .950 & .165 \\
\hline through songs. & Female & 90 & 4.18 & .815 & .087 \\
\hline $\begin{array}{l}\mathrm{t}(124)=2.09 \\
\mathrm{df}=124 \\
\text { sig. 2-tail=.038* } \\
\mathrm{p}<.005\end{array}$
\end{tabular}

With regard to the research question 4, on students' preferences for multimedia instruction, $81.8 \%$ of students said they enjoy learning English through songs. Youtube is an accessible learning source that can be used to capture songs and motion. Students are interested in singing English songs and learning English at the same time.

DVD presentations are the next most popular, with $76.9 \%$ of participants indicating they would like to learn English through watching DVDs in the English classroom. More than $70 \%$ of the students in this study said that watching DVDs with captions improved their understanding of the DVD's content. Consistent with previous studies by Hwang (2007), the present research suggests that the use of L2 captioned videos as an instructional tool in the EFL classroom provides learners with rich authentic visual content and comprehensible input.

In class, all students should have access to multimedia equipment so that they don't need to face the teacher directly. Some students may feel nervous when they are learning a foreign language. Therefore, using multimedia teaching may reduce some students' learning anxiety. Multimedia teaching methods emphasize the fact that the best form of interaction between the teacher and the student is unlike the traditional one-way teaching method. In an electronic environment, it is much easier to create multimedia teaching settings that develop collaborative skills and interaction, and reduce the learner's level of anxiety.

\section{CONCLUSION}

Overall, the present study reveals that multimedia environments have a positive impact on language learning for EFL college students in Taiwan. The results of the study indicate that the participants believe that the best way to learn English is through computer-assisted learning environments. More specifically, there is a positive relationship between reduced learning anxiety and use of a multimedia environment. Computer-assisted language learning instruction creates a non-threatening, positive and relaxed English learning environment and tends to help reduce learners' language learning anxiety and to motivate their learning. Teachers could design less stressful activities for their courses in order to help students to overcome foreign language anxiety and to improve their English proficiency. In other words, teachers should make students understand that scores do not reflect true language ability, but are only one of the indicators in assessing their language learning.

College students are particularly anxious about losing face in front of teachers and peers, and are afraid of making mistakes while speaking. This leads to a negative attitude towards language learning. Female students prefer to learn English through songs. This learning method creates a relaxed and less stressful learning process. 
To summarize, the findings of this study claim that English instructors can be more aware of students' psychological needs during the process of language acquisition. Moreover, they should provide proper multimedia instruction in the class in order to help overcome students' foreign language learning anxiety.

\section{APPENDIX LANGUAGE LEARNING ANXIETY QUESTIONNAIRE}

\section{Background Information Questionnaire}

Academic Major:

1. Gender:_ male female

2. Age: $\quad 18-20 \quad 21-23$

3. When did you start to learn English? over 24

\section{Kindergarten__ Primary school \\ II. English version of FLCAS (Foreign Language Classroom Anxiety Scale)}

Statements (1) through (33) describe how you feel about learning English. Please indicate whether you (1) Strongly Disagree, (2) Disagree, (3) Neither Agree or disagree, (4) Agree, or (5) Strongly Agree. Please read each statement carefully, give your first reaction to each statement, and mark an answer for every statement.

\section{Strongly Disagree, (2) Disagree, (3) Neither Agree or disagree, (4) Agree, or (5) Strongly Agree}

1. I never feel quite sure of myself when I am speaking in my foreign language class. $\quad \begin{array}{rrrrr}1 & 2 & 3 & 4 & 5\end{array}$

2. I don't worry about making mistakes in language class.

$\begin{array}{lllll}1 & 2 & 3 & 4 & 5\end{array}$

3. I tremble when I know that I'm going to be called on in language class.

4. It frightens me when I don't understand what the teacher is saying in the foreign language.

5. It wouldn't bother me at all to take more foreign language classes.

6. During language class, I find myself thinking about things that have nothing to do with the course.

7. I keep thinking that the other students are better at languages than I am.

8. I am usually at ease during tests in my language class.

9. I start to panic when I have to speak without preparation in language class.

10. I worry about the consequences of failing my foreign language class.

11. I don't understand why some people get so upset over foreign language classes.

12. In language class, I can get so nervous when I forget things I know.

13. It embarrasses me to volunteer answers in my language class.

14. It would not be nervous speaking in the foreign language with native speakers.

15. I get upset when I don't understand what the teacher is correcting.

16. Even if I am well prepared for language class, I feel anxious about it.

17. I often feel like not going to my language class.

18. I feel confident when I speak in foreign language class.

19. I am afraid that my language teacher is ready to correct every mistake I make.

20. I can feel my heart pounding when I'm going to be called on in language class.

21 . The more I study for a language test, the more confused I get.

22 . I don't feel pressure to prepare very well for language class.

23. I always feel that the other students speak the language better than I do.

24. I feel very self-conscious about speaking the foreign language in front of other students.

25 . Language class move so quickly I worry about getting left behind.

$\begin{array}{lllll}1 & 2 & 3 & 4 & 5\end{array}$

$\begin{array}{lllll}1 & 2 & 3 & 4 & 5\end{array}$

$\begin{array}{lllll}1 & 2 & 3 & 4 & 5\end{array}$

$\begin{array}{lllll}1 & 2 & 3 & 4 & 5\end{array}$

$\begin{array}{lllll}1 & 2 & 3 & 4 & 5\end{array}$

$\begin{array}{lllll}1 & 2 & 3 & 4 & 5\end{array}$

$\begin{array}{lllll}1 & 2 & 3 & 4 & 5\end{array}$

$\begin{array}{lllll}1 & 2 & 3 & 4 & 5\end{array}$

$\begin{array}{lllll}1 & 2 & 3 & 4 & 5\end{array}$

$\begin{array}{lllll}1 & 2 & 3 & 4 & 5\end{array}$

$\begin{array}{lllll}1 & 2 & 3 & 4 & 5\end{array}$

$\begin{array}{lllll}1 & 2 & 3 & 4 & 5\end{array}$

$\begin{array}{lllll}1 & 2 & 3 & 4 & 5\end{array}$

$\begin{array}{lllll}1 & 2 & 3 & 4 & 5\end{array}$

$\begin{array}{lllll}1 & 2 & 3 & 4 & 5\end{array}$

$\begin{array}{lllll}1 & 2 & 3 & 4 & 5\end{array}$

$\begin{array}{lllll}1 & 2 & 3 & 4 & 5\end{array}$

26. I feel more tense and nervous in my language class than in my other classes.

27 . I get nervous and confused when I am speaking in my language class.

28. When I'm on my way to language class, I feel very sure and relaxed.

29. I get nervous when I don't understand every word the language teacher says.

30. I feel overwhelmed by the number of rules you have to learn to speak a foreign language. $\begin{array}{llllll}1 & 2 & 3 & 4 & 5\end{array}$

31. I am afraid that the other students will laugh at me when I speak the foreign language. $\quad \begin{array}{llllll}1 & 2 & 3 & 4 & 5\end{array}$

$\begin{array}{lllllll}32 . & \text { I would probably feel comfortable around native speakers of the foreign language. } & 1 & 2 & 3 & 4 & 5\end{array}$

33. I get nervous when the language teacher asks questions which I haven't prepared in advance.

III. Perceptions on Freshman English course with Multimedia Instruction

(1) Strongly Disagree, (2) Disagree, (3) Neither Agree or disagree, (4) Agree, or (5) Strongly Agree.

1. I learn how to work with others from the group presentation in class. $\quad 1 \quad 2 \quad 3 \quad 4 \quad 5$

2. I improve my listening skills when the class is in the English environment. $\quad 1 \quad 2 \quad 3 \quad 4 \quad 5$

3. The website English learning sources such as CNN learning sources, esl-lab listening help my English.

$\begin{array}{lllll}1 & 2 & 3 & 4 & 5\end{array}$

4. I enjoy listening to ESL-lab listening exercises because it improves my listening skills. $\quad \begin{array}{llllll}1 & 2 & 3 & 4 & 5\end{array}$

5. Watching video in English class also interests me to learn English.

6. I think English captions help me understand the conversation better.

7. I think English captions hinder my understanding of the content. 
8. English captions can improve my listening skills.

9. English captions can improve my vocabulary.

10. Making the English video is interesting and encourages your language learning.

11. I like to learn English through songs.

12. I like to learn English through reading novels.

13. I like to learn English through online learning websites.

14. I like to learn English through lectures by teachers.

15. I like to learn English through group tasks.

16. I think learning holidays help me understand more about foreign cultures.

17. I think Multimedia (i.e.: computers, DVD, Youtube, PPT...) is a good technique to learn English.

18. I think Multimedia will reduce my English learning anxiety.

19. I think English Passport (i.e.: English corner, CEPT....) improve my English skills

$\begin{array}{lllll}1 & 2 & 3 & 4 & 5\end{array}$

$\begin{array}{lllll}1 & 2 & 3 & 4 & 5\end{array}$

$\begin{array}{lllll}1 & 2 & 3 & 4 & 5\end{array}$

$\begin{array}{lllll}1 & 2 & 3 & 4 & 5\end{array}$

$\begin{array}{lllll}1 & 2 & 3 & 4 & 5\end{array}$

$\begin{array}{lllll}1 & 2 & 3 & 4 & 5\end{array}$

$\begin{array}{lllll}1 & 2 & 3 & 4 & 5\end{array}$

$\begin{array}{lllll}1 & 2 & 3 & 4 & 5\end{array}$

$\begin{array}{lllll}1 & 2 & 3 & 4 & 5\end{array}$

$\begin{array}{lllll}1 & 2 & 3 & 4 & 5\end{array}$

$\begin{array}{lllll}1 & 2 & 3 & 4 & 5\end{array}$

$\begin{array}{lllll}1 & 2 & 3 & 4 & 5\end{array}$

20. What are Multimedia instruction you like the most?

\section{ACKNOWLEDGMENT}

This paper was supported in part by the Chung Shan Medical University, Taiwan ROC, under Grant F0110031.

\section{REFERENCES}

[1] Aida, Y. (1994). Examination of Horwitz, Horwitz, \& Copes' construct of foreign language anxiety: The case of students of Japanese. The Modern Language Journal, 78, 155-168.

[2] Bailey, K. M. (1983). Competitiveness and anxiety in adult second language learning: Looking at and through the diary studies. In H. W. Seliger \& M. H. Long (Eds.), Classroom oriented research in second language acquisition (pp. 67-102). Rowley, MA: Newbury House.

[3] Blake, R. (1998). The role of technology in second language learning. In Heidi Byrnes, (ed.), Learning Foreign and Second Languages: Perspectives in Research and Scholarship. 209 -237. New York, NY: The Modern Language Association of America.

[4] Chang, Y. M., Lin, C. Y., \& Lee, Y. K. (2005). The preferences of young children for images used in dynamic graphical interfaces in computer-assisted English vocabulary learning. Displays, 26(4-5), 147-152.

[5] Dwyer, M. (1978). Strategies for improving visual learning. State College, PA: Learning Services.

[6] Hartman, F. (1961). Single and multiple channel communication: A review of research and a proposed model. Audio Visual Communications Review, 9(6), 235-262.

[7] Horwitz, E. K. (2001). Language anxiety and achievement. Annual Review of Applied Linguistics, 21, $112-126$.

[8] Horwitz, E. K. , Horwitz, M. B., \& Copes, J., (1986). Foreign language classroom anxiety. Modern Language Journal, 70 , $125-132$.

[9] Hwang, Y. L., \& Huang, P. W. (2007, May). Playing English captions: EFL learners' vocabulary learning. The Proceedings of Taiwan TESOL Conference (pp. 300-314). Taiwan ELT Publishing Co. LTD.

[10] Hwang, Y. L., \& Huang, P. W. (2010). A study of EFL college students' language anxiety in multimedia environments. The International Journal of the Humanities. 8(2), 367-378.

[11] Krashen, S. (1985). The input hypothesis and its rivals, In: N. Ellis(Ed.), Implicit and explicit learning of language. New York: Academic Press. 45-77.

[12] Krashen, S. (1999). Three arguments against whole language and why they are wrong. Portsmouth, NH: Heinemann.

[13] Krashen, S. (2005). Explorations in language acquisition and use: The Taipei lectures. Portsmouth, NH: Heinemann.

[14] Levie, H., \& Lentz, R. (1982). Effects of text illustrations: A review of research. Educational Communication and Technology Journal, 30(4), 195-232.

[15] MacIntyre, P. D. \& Charos, C., (1996). Personality, attitudes, and affect as predictors of second language communication. Journal of Language and Social Psychology. 15, 3-26.

[16] Moore, M., Burton, K., \& Mayers, J. (1995). Multiple-channel communication: the theoretical and research foundations of multimedia. In D. H. Jonassen (Ed.), Handbook of research on communication and educational technology. Washington, DC: Association for Educational Communications and Technology.

[17] Okan, Z. (2008). Computing laboratory classes as language learning environments. Learning Environments Research, 11(1), $31-48$.

[18] Oxford, R. (1990). Language Learning Strategies. What every teacher should know. Massachusetts: Heinle \& Heinle Publishers.

[19] Scovel, T. (1978). The effect of affect on foreign language learning: A review of the anxiety research. Language Learning, 28, $128-142$.

[20] Spielberger, C. (1983). Manual for the State-Trait Anxiety Inventory. CA: Consulting Psychologists Press.

[21] Tamburini, F. (1999). A multimedia framework for second language teaching in self-access environments. Computers \& Education, 32(2), 137-149.

[22] Torgesn, T. (1995). An Evaluation of Computer-assisted Instruction in Phonological Awareness with Below Average Readers. Journal of Educational Computing Research, 13, 121-137.

[23] Tsou, W., Wang, W., \& Tzeng, Y. (2006). Applying a multimedia storytelling website in foreign language learning. Computers and Education, 47(1), 17-28.

[24] Underwood, J. (1984). Linguistics, computers and the language teacher: A communicative approach. Rowley, MA: Newbury House.

[25] Yashima, T. (2002). Willingness to communicate in L2: The Japanese EFL context. Modern Language Journal, 86, 54-66. 
[26] Yashima, T., Zenuk-Nishide, L., \& Shimizu, K. (2004). The Influence of attitudes and affect on willingness to communicate and second langue communication. Language Learning, 54, 119-152.

[27] Young, D. J. (1991). Creating a low-anxiety classroom environment: What does language anxiety research suggest? Modern Language Journal, 75, 426-437.

Peiwen Huang is an assistant professor of Applied Foreign Languages Department at the National Formosa University in Taiwan. She teaches courses in Multimedia English and Internet English. She has published incessantly at the international conference in the field of Educational Technology on topics dealing with web-based instruction, computer mediated communication, and second-language learning.

Yanling Hwang is an associate professor in the Department of Applied Foreign Languages at Chung Shan Medical University in Taiwan. Her research interests include CALL, second language acquisition and language teaching and learning. She is the member of the curriculum development at CSMU. 